\title{
Trends in postgraduate medical education in Iran
}

\author{
Shima Tabatabai ${ }^{*}$, Seyed Amir Mohsen Ziaee $^{2}$ \\ From Health Services Research: Evidence-based practice \\ London, UK. 1-3 July 2014
}

\section{Background}

Iran is designing an evidence-based plan for promoting postgraduate medical education and efficient distribution of health professional human resources. An important part of this program is foresight studies for post graduate medical education considering the important trends affecting the future of health status and postgraduate medical education in Iran. In this article, we clarify such trends in Iran.

\section{Methods}

For this study, we used a systematic review of current evidence about the mega trends affecting the future of medical education. Also we gathered opinions of key stakeholders in expert panels.

\section{Results}

Following trends identified as affecting the health system and post graduate medical education in Iran: demographic changes; epidemiologic transition; physician work patterns changes, female specialists number growth, changes in patients' expectations of health services; growth in information and communication technologies; new advances in diagnostic and therapeutic technologies.

\section{Conclusions}

The present study found that trends affecting postgraduate medical education in Iran. In the near future, medical education in Iran will need to undergo major changes. When planning for these changes, decision-makers should consider the various trends that affect education.

\section{Authors' details}

${ }^{1}$ School of Medical Education, Shahid Beheshti University of Medical Sciences, Tehran, Iran. ${ }^{2}$ Shahid Labbafinejad Medical Center, Shahid Beheshti University of Medical Sciences, Tehran, Iran.

'School of Medical Education, Shahid Beheshti University of Medical Sciences, Tehran, Iran

Full list of author information is available at the end of the article
Published: 7 July 2014

doi:10.1186/1472-6963-14-S2-P124

Cite this article as: Tabatabai and Ziaee: Trends in postgraduate medical education in Iran. BMC Health Services Research 2014 14(Suppl 2):P124.
Submit your next manuscript to BioMed Central and take full advantage of:

- Convenient online submission

- Thorough peer review

- No space constraints or color figure charges

- Immediate publication on acceptance

- Inclusion in PubMed, CAS, Scopus and Google Scholar

- Research which is freely available for redistribution
() Biomed Central 